tor Pawłowska zwróciła uwagę, że w niejednej sytuacji sprzeciw sumienia przestaje być konstruktywny, ponieważ możliwości działania są zdeterminowane przez posiadane zasoby. Brak wewnętrznej zgody na daną sytuację nie zmieni tej sytuacji. Odpowiadając, ks. Gocko stwierdził, że należy dążyć do zmiany zauważonych patologii, gdy jest to możliwe i na ile jest to możliwe. Sprzeciw sumienia tak naprawdę oznacza odmowę podjęcia działania, które się uważa za niegodziwe w tak poważnym stopniu, że w grę wchodzi kwestia zbawienia. Ksiadz Sobkowiak dopowiedział, że znak sprzeciwu sumienia jest czytelny tylko tam, gdzie stoi za nim prawdziwe świadectwo.

PIOTR KIENIEWICZ

\title{
OBRADY KOMITETU REGIONALNEGO EUROPY ŚWIATOWEJ ORGANIZACJI CATHOLIC THEOLOGICAL ETHICS IN THE WORLD CHURCH (CTEWC) Berlin 27-29 czerwca 2013 r.
}

W dniach 27-29 czerwca 2013 roku w Akademii Katolickiej w Berlinie odbyło się spotkanie przedstawicieli organizacji Catholic Theological Ethics in the World Church (CTEWC), w którym uczestniczyli członkowie Komitetu Planującego Antoni Autiero z Uniwersytetu Münster w Niemczech, James F. Keenan, SJ i Andrea Vicini z Boston College w USA, a także przedstawiciele Komitetu Regionalnego Europy. Wśród reprezentantów Europy Wschodniej byli: Slavomir Dlugos z Wiednia, Roman Globokar z Ljubljany, Konrad Glombik z Opola, Katica Knezović z Zagrzebia, Jaroslav Lorman z Pragi, Zorica Maros z Sarajewa i Petr Štica z Pragi. Teologów z Europy Zachodniej reprezentowali: Phillipe Bordeyne z Paryża, Julie Clague z Glasgow, François-Xavier Dumortier z Rzymu, Marianne Heimbach-Steins z Münster, Martin M. Lintner z Bresannone, Julio Martínez z Comillas, Martin McKeever z Rzymu, Sigrid Müller z Wiednia i Paul Schotsmans z Leuven. Celem obrad była analiza współczesnych przemian, z którymi konfrontowani są przedstawiciele etyki teologicznej w krajach Europy Wschodniej i Zachodniej, oraz próba określenia strategii wspólnych przyszłych działań w ramach organizacji CTEWC.

Pierwszy dzień spotkania był poświęcony problematyce przemian, w obliczu których stają współcześnie teologowie moraliści w krajach europejskich. Dotyczą one różnych obszarów ich działalności. Pierwszym z nich są przemiany w zakresie aktywności teologów moralistów, w którym językowe i narodowe granice określają zdolności do prowadzenia badań i publikowania ich wyników. Zmiany nastąiły zwłaszcza w odniesieniu do jednej określonej, tradycyjnej wizji teologii moralnej. Szczególnie bioetyka domaga się współcześnie uwzględnienia aspektów etyki społecznej. Sami teologowie moraliści stają wobec wielu oczekiwań, do których należy m.in. prowadzenie badań i prac naukowych, dydaktyka, kwestie administracyjne, studium, w ramach których spotykają się z różnymi przeszkodami. Inną przestrzenią przemian jest miejsce teologów moralistów w Kościele, środowisku uniwersyteckim i społeczności lokalnej. Zdarza się, że w ramach społeczności Kościoła przedstawiciele etyki teologicznej mu- 
szą bronić samych siebie przed fałszywie przypisywanymi im cechami i bywają określani jako nieortodoksyjni. Wypełnianie przez nich zadania odczytywania znaków czasu spotyka się z niezrozumieniem, zarówno w laickich mediach, jak i w środowiskach uniwersyteckich i gnostyckich środowiskach w społeczeństwie, co prowadzi do podważania wartości i naukowości teologii. Miejsce katolickich etyków teologicznych w Kościele, w środowiskach akademickich i społeczeństwie lokalnym bywa niepewne, czego doświadczają naukowcy zarówno w krajach Europy Wschodniej, jak i Zachodniej. Trzecią przestrzenią współczesnych przemian jest dla teologów moralistów ich przyszłość. Niepewność dotycząca miejsca aktywności stanowi podstawę obaw nie tylko w odniesieniu do przyszłości teologów moralistów, ale także przyszłości etyki teologicznej. Chodzi zwłaszcza o instancję, która zagwarantuje wypełnianie zadań akademickich przez teologów moralistów. Niemniej obawy dotyczą także studentów, racji, dla których decydują się oni na studia teologiczne i je kontynuuja, oraz możliwości podejmowania przez nich pracy po ich ukończeniu.

Przemiany dokonujące się na wspomnianych płaszczyznach dotykają zarówno instytucji, w których teologowie moraliści podejmują swoją aktywność, jak i doświadczane są przez nich osobiście. Podczas obrad nie zdołano zaprezentować całej palety przemian w różnych krajach europejskich ani zdefiniować ich istoty i zdiagnozować ich złożonych przyczyn. Dokonała się raczej wymiana doświadczeń teologów moralistów różnych krajów europejskich, konfrontowanych z dokonującymi się przemianami. Dopełnieniem tego ogólnego przedstawienia stała się dyskusja w małych grupach, której przedmiotem były przemiany w sferze nauczania i prowadzenia prac naukowych, podejmowania badań naukowych oraz w zakresie instytucji naukowo-badawczych.

Drugi dzień obrad był poświęcony strategiom przyszłości w obliczu dokonujących się przemian. Jego celem było opracowanie podstaw europejskiego komitetu regionalnego CTEWC i jego własnej agendy na najbliższe lata. Główna dyskusja została poprzedzona raportem komitetów regionalnych CTEWC z Afryki i Azji, który przedstawili ich przewodniczący: Orobator Agbonkhianmeghe z Nigerii i Lúcás Chan Yiu Sing z Hong Kongu. W swoich wystąpieniach dokonali prezentacji strategii działań komitetów regionalnych, uwzględniając zwłaszcza program nauczania etyki teologicznej, organizację konferencji regionalnych, rozwój elit, prowadzenie badań naukowych i działalności wydawniczej, funkcjonowanie komitetu regionalnego oraz komunikacji i współpracy między różnymi krajami i regionami.

W czasie dyskusji dotyczącej przyszłości działania w ramach europejskiego Komitetu Regionalnego CTEWC zwrócono uwagę na konieczność podejmowania wspólnych inicjatyw, dalszych spotkań oraz działań pro-aktywnych, a nie reaktywnych. Do działań, które należy w przyszłości podjać, zaliczono m.in.: wymianę informacji i kooperację, opracowanie programów rozwoju dla doktorantów, wymianę doświadczeń między naukowcami, opracowanie koncepcji teologii moralnej fundamentalnej, promocję etyki społecznej, potrzebę większego uwzględnienia interdyscyplinarności w prowadzeniu badań naukowych z teologii moralnej, komunikację i wymianę doświadczeń między teologami i instytucjami kościelnymi, interakcję między instytucjami, projektami i problemami globalnymi i lokalnymi oraz kwestię strony internetowej CTEWC. 
Pomimo iż nie znaleziono dla wszystkich kwestii prostych i konkretnych rozwiązań, a wiele z omawianych spraw pozostało na płaszczyźnie propozycji i pytań, to stały się one punktem wyjścia dalszych przemyśleń. Wiele kwestii wiązało się z problemem organizacji dalszych spotkań, dla których przeszkodą nie powinien być zróżnicowany kontekst społeczny ani różnice w mentalności, tradycji i języku członków komitetu regionalnego. Można mówić o jednomyślności uczestników spotkania co do tego, że stanowi ono początek wspólnej wizji, która ma ważne znaczenie dla przyszłych pokoleń teologów dla społeczeństw Europy oraz jest adekwatną próbą odpowiedzi na wezwania globalizacji i sekularyzacji. W ramach spotkania odbyło się także seminarium poświęcone sposobom nauczania etyki teologicznej w przyszłości i promocji przyszłej generacji teologów moralistów. Problematyka została przedstawiona z perspektywy azjatyckiej, amerykańskiej oraz europejskiej. Na zakończenie zapowiedziano kolejny kongres CTEWC, który odbędzie się w 2018 roku, oraz spotkanie Komitetu Regionalnego Europy, które zaplanowano na 2016 rok.

Obrady zwieńczył udział uczestników konferencji w uroczystości na zakończenie kolejnego roku działalności Akademii Katolickiej w Berlinie. Po uroczystej Mszy św. odbyła się konferencja z licznym udziałem mieszkańców Berlina, podczas której został odczytany wykład nieobecnej Lindy Hogan z Dublina na temat relacji religii i polityki, a Orobator Agbonkhianmeghe wygłosił referat na temat aktualnych problemów społecznych w Afryce. Na zakończenie została zaprezentowana działalność organizacji Catholic Theological Ethics in the World Church.

Całość obrad i prowadzonych dyskusji zdominowało zagadnienie odmienności tradycji, mentalności, języka i problemów wschodnio- i zachodnioeuropejskich teologów moralistów, a jednocześnie woli współpracy w podejmowaniu wyzwań współczesności. Berlin jako miasto, które doświadczyło dramatycznego podziału i od prawie 25 lat zrasta się, tworząc nowoczesną metropolię w centrum Europy, jest znakiem dla teologów europejskich, że droga do kooperacji i dialogu jest długim i żmudnym, ale jednocześnie możliwym i pożądanym procesem.

KONRAD GLOMBIK

Uniwersytet Opolski

\section{SPRAWOZDANIE ZARZACDU STOWARZYSZENIA TEOLOGÓW MORALISTÓW W POLSCE Z DZIAŁALNOŚCI W LATACH 2006-2013}

Publikowane tu Sprawozdanie Zarządu Stowarzyszenia Teologów Moralistów (dalej STM) w Polsce obejmuje siedem lat jego pracy. W zasadniczo niezmienionym składzie pełnił on swoją funkcję w czasie dwu kadencji wyborczych w latach: 2006-2010 i 2010-2013. Dlatego tekst został podzielony na dwie części i - poza niewielkimi zmianami redakcyjnymi - odpowiada temu, co Przewodniczacy STM przedstawiał w czasie Walnych Zebrań sprawozdawczo-wyborczych po zakończeniu każdej kadencji. 